Case Report

\title{
Ectopic Intratracheal Thyroid: A Rare Cause of Airway Obstruction
}

\author{
Waheed Rahman, Nafil Ishaq Arimbrathodi (D), Faisal Abdulkader, Hussain Al-Enazi, and \\ Zeynel A. Dogan
}

Department of Otolaryngology, Head and Neck Surgery, Hamad Medical Corporation, Doha, Qatar

Correspondence should be addressed to Nafil Ishaq Arimbrathodi; nafil42@gmail.com

Received 19 July 2017; Revised 12 November 2017; Accepted 20 November 2017; Published 27 January 2018

Academic Editor: Gianluca Donatini

Copyright (c) 2018 Waheed Rahman et al. This is an open access article distributed under the Creative Commons Attribution License, which permits unrestricted use, distribution, and reproduction in any medium, provided the original work is properly cited.

Ectopic intratracheal thyroid tissue (EITT) is a rare abnormality with only limited cases reported so far. The presenting symptoms can be very similar to those of bronchial asthma. We discuss the case of a 29-year-old man with subglottic ectopic thyroid, with a history of thyroid surgery for goiter, which has been managed with laser-assisted endoscopic approach. We have also included presenting symptoms, pathophysiology, diagnosis, and management of EITT. We aim to include EITT in the differentials of airway obstruction, particularly in those patients who have goiter or previous thyroid surgeries.

\section{Introduction}

Ectopic thyroid tissue (ETT) is a rare entity, which can be seen anywhere in the midline from the base of the tongue to mediastinum. Among them, the laryngotracheal region has the rarest occurrence that can cause upper airway obstruction. Since ectopic intratracheal thyroid tissue (EITT) is a rare condition, its symptoms can easily be mistaken for those of asthma. An associated hypothyroid level can lead to enlargement of EITT and worsening of symptoms. We are discussing EITT-causing stridor in a young man with a history of thyroid surgery who missed thyroxine therapy.

\section{Case Report}

A 29-year-old male, nonsmoker, presented to the emergency department with breathing difficulty. He had increasing dyspnea since few months, for which his general practitioner had treated him for asthma. Five years earlier, the patient had undergone thyroid surgery for goiter with subsequent thyroxine replacement therapy. But the patient missed the course and follow-up.
During the current presentation, fiber optic endoscopy showed bilateral mobile vocal cords and narrow infraglottic trachea with a right-sided subglottic mass.

CT showed subglottic soft tissue mass of about $4 \times 4.7 \times 2.4 \mathrm{~cm}$ in the craniocaudal, anteroposterior, and transverse dimensions, respectively, extending at the level of C4, C5, C6, and C7 vertebrae, and it causes marked narrowing of the airways (Figures $1(\mathrm{a})$ and $1(\mathrm{~b})$ ).

On admission, TSH was $7.82 \mathrm{mIU} / \mathrm{L}$ (normal range $0.5-5.0 \mathrm{mIU} / \mathrm{L}$ ) and free $\mathrm{T} 4$ was $13.31 \mathrm{mcg} / \mathrm{dl}$ (normal range $7.0-14.0 \mathrm{mcg} / \mathrm{dl})$.

The patient underwent emergency tracheobronchoscopy which showed subglottic mass (Figure 2). Biopsy of mass done and the patient was tracheostomised. The histopathology and immunostain study result confirmed multinodular goiter associated with hyperplastic nodules with no evidence of malignancy.

We have done microlaryngoscopic excision of the subglottic mass utilizing $\mathrm{CO}_{2}$ laser. The histopathology confirmed ectopic thyroid tissue (Figures 3-5). The patient weaned from tracheostomy tube and discharged on thyroxin supplement, and regular follow-up with ENT and endocrinology was given. 


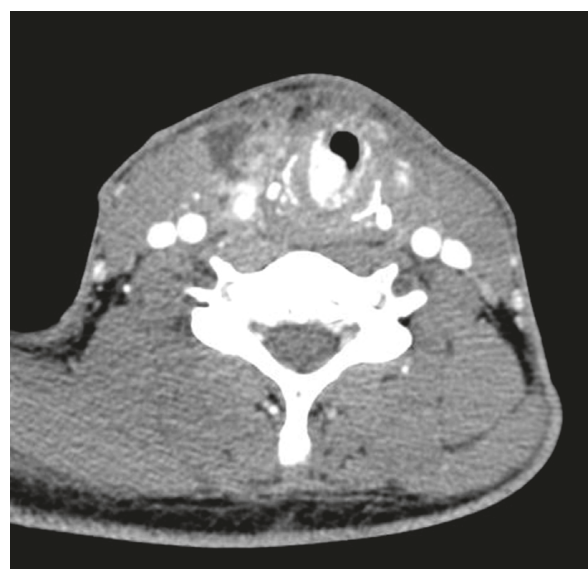

(a)

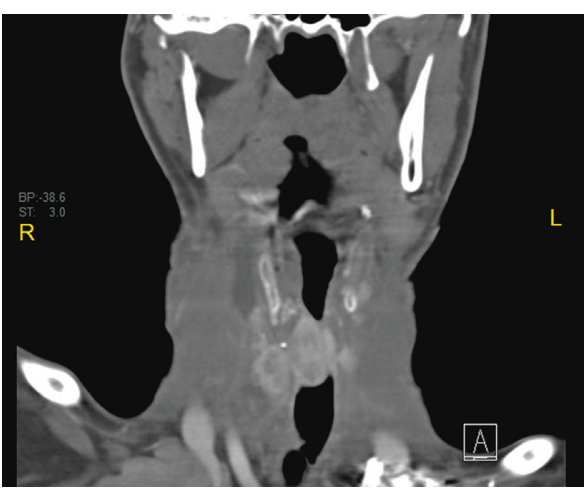

(b)

Figure 1: Contrast-enhanced CT showing subglottic soft tissue mass extending at the level of C4, C5, C6, C7 vertebrae, causing marked narrowing of the airways. (a) is axial view and (b) is coronal view.

\section{Discussion}

Being a rare phenomenon, the number of cases reported with ETT so far is less than $500[1,2]$. It is most commonly found in the lingual, sublingual, thyroglossal, laryngotracheal, and lateral areas. Very rarely, it has been described at the esophagus, mediastinum, heart, pancreas, adrenals, small intestine, and cutaneous area [3-12].

The percentage of ETT in trachea contributes 6-7\% of all primary endotracheal tumors [13]. The first case was described in 1875 by Ziemssen [14-16]. The majority of the cases were reported from endemic goiter regions of the world [17]. Though EITT has been found anywhere from glottis to tracheal bifurcation, its most common appearance is as a submucosal mass on the lateral subglottic and upper tracheal wall [17-19].

The origin of EITT is explained by two theories. "The malformation theory" by Ziemssen in 1875 postulates that tracheal cartilage which develops later splits the thyroid gland, creating a small ectopic nest in the tracheal cavity $[15,16]$. "The ingrowth theory" by Paltauf in 1892 states that the improper development of the mesenchymal tissue between the thyroid and trachea results in adherence of the former to the latter thus permitting the ingrowth [20].

Usually, patients are symptomless until a change in their hormonal status happen. Stimulatory factors including TSH, epidermal growth factor, and human chorionic gonadotropin could stimulate thyroid growth [21]. Symptomatic EITT causes difficulty in breathing, cough, stridor, and dysphagia. On physical examination, differentiating stridor of EITT from wheezing of asthma is not easy.

The findings suggestive of malignancy of EITT include multiple nodules, ulceration, and bleeding. $11 \%$ of EITT has been reported to undergo malignant transformation [16]. The most common malignancy found is papillary thyroid carcinoma [22, 23].

In a symptomatic patient, complete ENT examination should be carried out. Laboratory studies including thyroid assessment should also be conducted. Indirect laryngoscopy, flexible laryngoscopy, and CT and MR studies must be included. Radionuclide studies are highly sensitive and specific

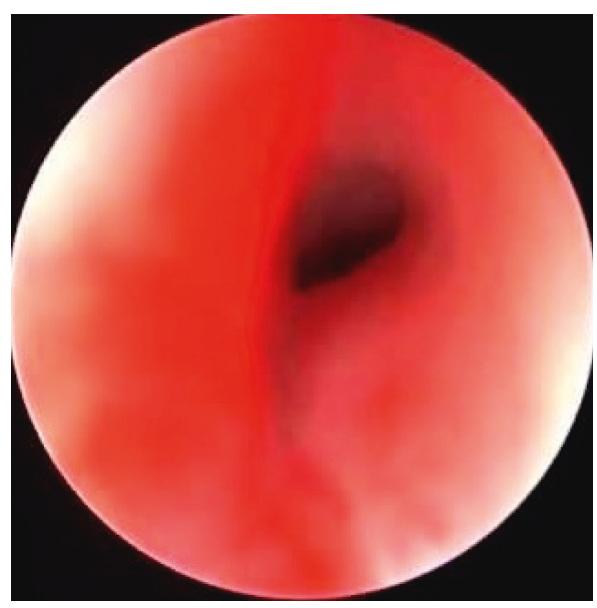

FIgURE 2: Tracheo-laryngoscopic examination showing subglottic mass obstructing the airway.

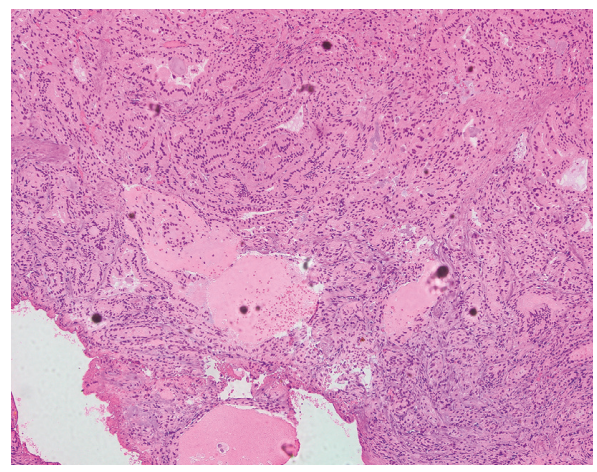

FIgURE 3: Histopathology showing thyroid follicles filled with colloid.

in detecting functional EITT [24]. Tc-99m pertechnetate scans high value in assessing the size, distribution, and activity of EITT. Fusion imaging techniques like single photon emission tomography-computed tomography (SPECT-CT) is valuable in diagnosis of EITT. 


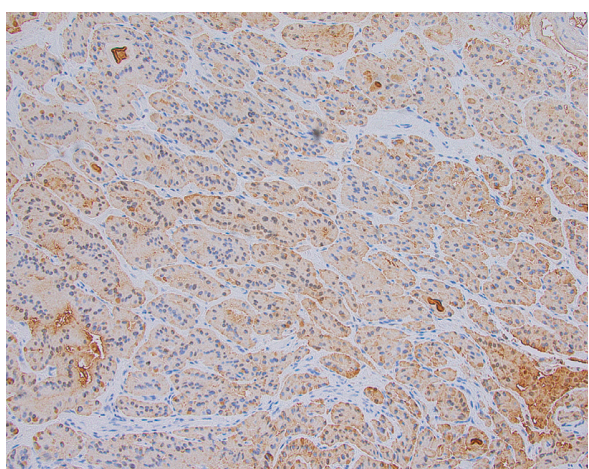

Figure 4: Positive cytoplasmic staining with thyroglobulin immunostain confirming the thyroid origin.

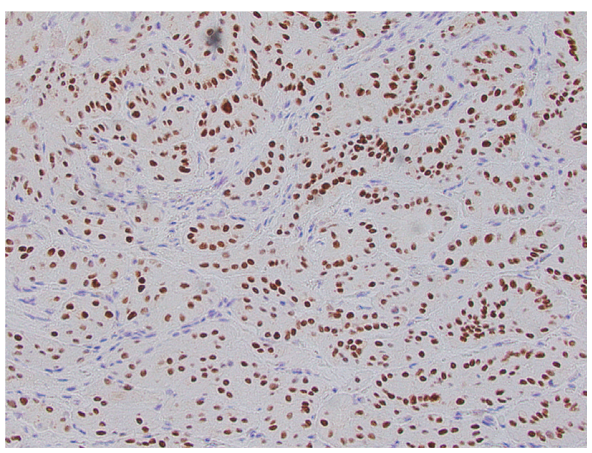

Figure 5: Positive nuclear staining with TTF-1 immunostain confirming the thyroid origin.

If associated with multinodular goiter, FNAC can be done. Direct laryngobronchoscopy will help in proper visualization of mass and performing biopsy. Since there is a chance of severe hemorrhage, a biopsy should be carried carefully [16].

The factors determining management of EITT include the size of lesion, the patient's age, the presence of local symptoms, the status of thyroid function, and histological findings. Surgical excision, radioiodine ablation, and thyroid suppression therapy are the main treatment options adapted. The complete surgical excision is indicated in symptomatic cases and in cases of histological malignancy. The two common surgical methods are removal via an endoscopic laser-assisted approach as in the present case and removal of the tumor via an open cricoid procedure [25]. Postoperative thyroid suppression therapy is performed to prevent hypertrophy of residual tissue. Radioiodine ablation with hormonal suppression has only limited success [25]. The risks associated with ablation therapy include radiation thyroiditis and tracheitis. It can be useful in patients who refuse or are unfit for surgery. While considering all the management options, surgical removal should be counted as the best option for the long-term outcomes [26-28].

\section{Conclusion}

Even though EITT is a rare abnormality with few case reported in the literature, it must be included in the differentials in patients presenting with airway obstruction, particularly in those who have goiters or previous thyroid surgeries.

\section{Conflicts of Interest}

The authors declare that there are no conflicts of interest.

\section{References}

[1] A. Kalan and M. Tariq, "Lingual thyroid gland: clinical evaluation and comprehensive management," Ear, Nose, \& Throat Journal, vol. 78, no. 5, p. 340, 1999.

[2] J. S. Yoon, K. C. Won, I. H. Cho, J. T. Lee, and H. W. Lee, "Clinical characteristics of ectopic thyroid in Korea," Thyroid, vol. 17, no. 11, pp. 1117-1121, 2007.

[3] M. A. Salam, "Ectopic thyroid mass adherent to the oesophagus," Journal of Laryngology \& Otology, vol. 106, no. 8, pp. 746-747, 1992.

[4] T. C. Gamblin, G. R. Jennings, D. B. Christie III, W. M. Thompson, and M. L. Dalton, "Ectopic thyroid," Annals of Thoracic Surgery, vol. 75, no. 6, pp. 1952-1953, 2003.

[5] G. D. Rieser, K. P. Ober, R. J. Cowan, and A. R. Cordell, "Radioiodide imaging of struma cordis," Clinical Nuclear Medicine, vol. 13, no. 6, pp. 421-422, 1988.

[6] R. J. Williams, G. Lindop, and J. Butler, "Ectopic thyroid tissue on the ascending aorta: an operative finding," Annals of Thoracic Surgery, vol. 73, no. 5, pp. 1642-1643, 2002.

[7] T. Shiraishi, H. Imai, K. Fukutome, M. Watanabe, and R. Yatani, "Ectopic thyroid in the adrenal gland," Human Pathology, vol. 30, no. 1, pp. 105-108, 1999.

[8] E. Eyuboglu, M. Kapan, T. Ipek, Y. Ersan, and F. Öz, "Ectopic thyroid in the abdomen: report of a case," Surgery Today, vol. 29, no. 5, pp. 472-474, 1999.

[9] K. Maino, H. Skelton, J. Yeager, and K. J. Smith, "Benign ectopic thyroid tissue in a cutaneous location: a case report and review," Journal of Cutaneous Pathology, vol. 31, no. 2, pp. 195-198, 2004.

[10] T. Takahashi, H. Ishikura, H. Kato, T. Tanabe, and T. Yoshiki, "Ectopic thyroid follicles in the submucosa of the duodenum," Virchows Archiv A Pathological Anatomy and Histopathology, vol. 418, no. 6, pp. 547-550, 1991.

[11] E. Ihtiyar, S. Isiksoy, C. Algin, A. Sahin, S. Erkasap, and B. Yasar, "Ectopic thyroid in the gallbladder: report of a case," Surgery Today, vol. 33, no. 10, pp. 777-780, 2003.

[12] B. Gungor, T. Kebat, C. Ozaslan, and S. Akılll, "Intraabdominal ectopic thyroid presenting with hyperthyroidism: report of a case," Surgery Today, vol. 32, no. 2, pp. 148-150, 2002.

[13] J. Fish and R. M. Moore, "Ectepic thyroid tissue and ectopic thyroid carcinoma: a review of the literature and report of a case," Annals of Surgery, vol. 157, no. 2, pp. 212-222, 1963.

[14] L. Thoren, "Intratracheal goitre," Acta Chirurgica Scandinavica, vol. 95, pp. 455-512, 1947.

[15] Ziemssen, "Uber Kopfgeschwuelste im Innern des Kehlkopfs und der Luftrohre und ihre Entfernung," Beitr Kim Chir, vol. 41, pp. 1903-1904, 1875.

[16] E. A. Dowling, I. M. Johnson, F. C. Collier, and R. A. Dillard, "Intratracheal goiter: a clinico-pathologic review," Annals of Surgery, vol. 156, no. 2, pp. 258-267, 1962.

[17] E. N. Myers and I. P. Pantangco, "Intratracheal thyroid," Laryngoscope, vol. 85, no. 11, pp. 1833-1840, 1975. 
[18] A. M. Noyer and J. Friedberg, "Thyroglossal duct and ectopic thyroid disorders," Otolaryngologic Clinics of North America, vol. 14, no. 1, pp. 187-201, 1981.

[19] R. C. Bone, H. F. Biller, and T. M. Irwin, "Intralaryngotraheal thyroid," Annals of Otology, Rhinology \& Laryngology, vol. 81, no. 3, pp. 424-428, 1972.

[20] R. Paltauf, "Zur enntniss der Schilddrusentumoren im Innern des Kehlkopfs und der Luftrohre," Beitrage Zur Pathologischen Anatomie Und Zur Allgemeinen Pathologie, vol. 11, pp. 71-89, 1892.

[21] H. Dossing, K. E. Jorgensen, E. Oster-Jorgensen, A. Krogdahl, and L. Hegedüs, "Recurrent pregnancy- related upper airway obstruction caused by intratracheal ectopic thyroid tissue," Thyroid, vol. 9, pp. 955-958, 1999.

[22] C. K. Hari, M. J. Brown, and I. Thompson, "Tall cell variant of papillary carcinoma arising from ectopic thyroid tissue in the trachea," Journal of Laryngology \& Otology, vol. 113, no. 2, pp. 183-185, 1999.

[23] A. C. See, S. G. Patel, P. Q. Montgomery, P. H. Rhys Evans, and C. Fisher, "Intralaryngotracheal thyroid-ectopic thyroid or invasive carcinoma?," Journal of Laryngology \& Otology, vol. 112, no. 7, pp. 673-676, 1998.

[24] A. Sood and R. Kumar, "The ectopic thyroid gland and the role of nuclear medicine techniques in its diagnosis and management," Hellenic Journal of Nuclear Medicine, vol. 11, no. 3, pp. 168-171, 2008.

[25] L. Soylu, F. Kiroglu, C. Ersoz, C. Özcan, and B. Aydoğan, "Intralaryngotracheal thyroid," American Journal of Otolaryngology, vol. 14, no. 3, pp. 145-147, 1993.

[26] M. Khan, P. G. Michaelson, and M. L. Hinni, "Intratracheal ectopic thyroid tissue presenting with protracted airway obstruction: a case report," Ear, Nose, \& Throat Journal, vol. 87, no. 8, pp. 476-477, 2008.

[27] B. Karakullukcu, M. G. Guvenc, H. Cansiz, F. Oktem, and B. Oz, "Intratracheal ectopic thyroid: case report and review," Ear, Nose, \& Throat Journal, vol. 86, no. 7, pp. 406-408, 2007.

[28] H. E. Bowen-Wright and J. Jonklaas, "Ectopic intratracheal thyroid: an illustrative case report \& literature review," Thyroid, vol. 15, pp. 478-484, 2005. 


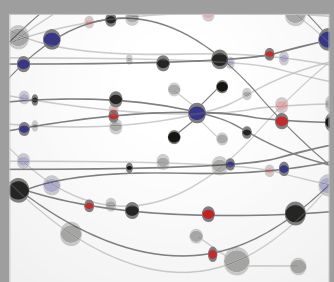

The Scientific World Journal
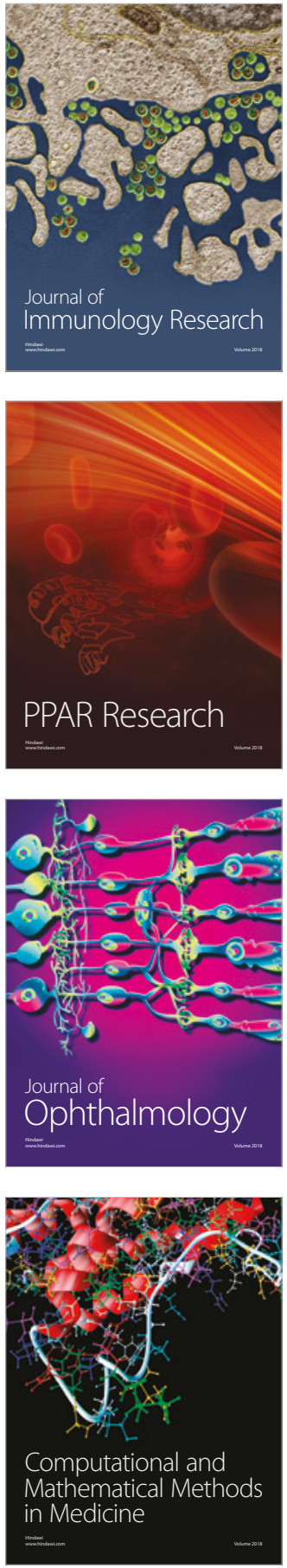

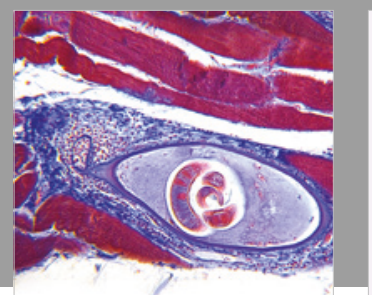

Gastroenterology Research and Practice

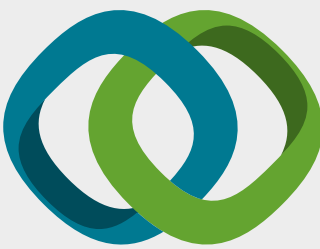

\section{Hindawi}

Submit your manuscripts at

www.hindawi.com
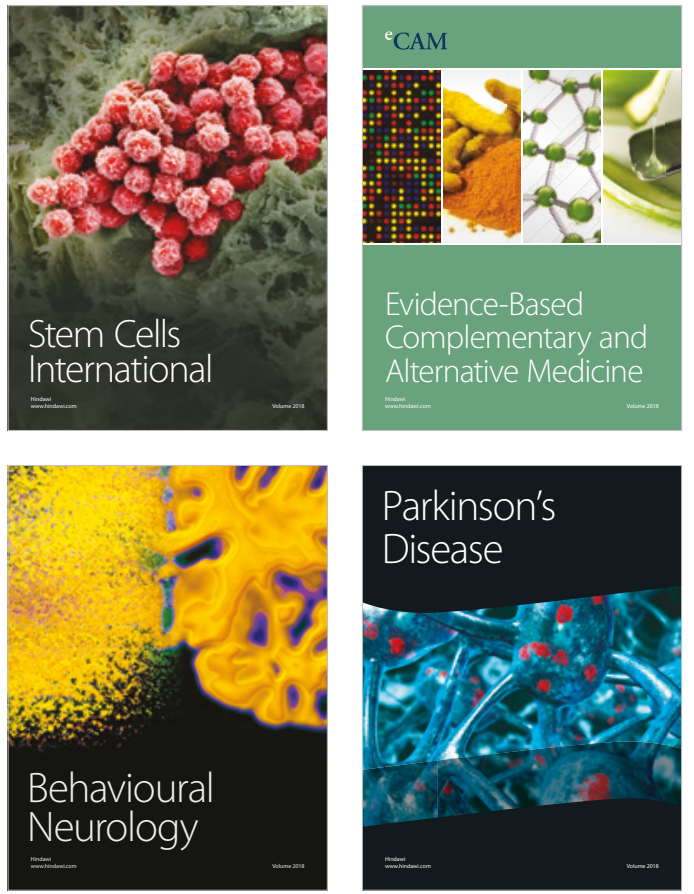

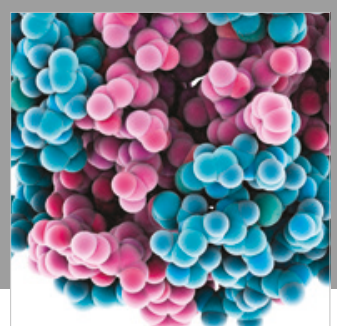

ournal of

Diabetes Research

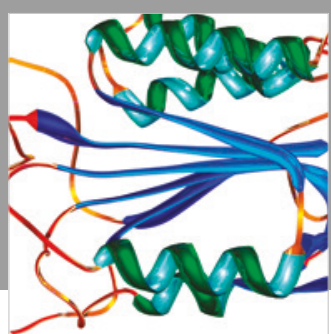

Disease Markers
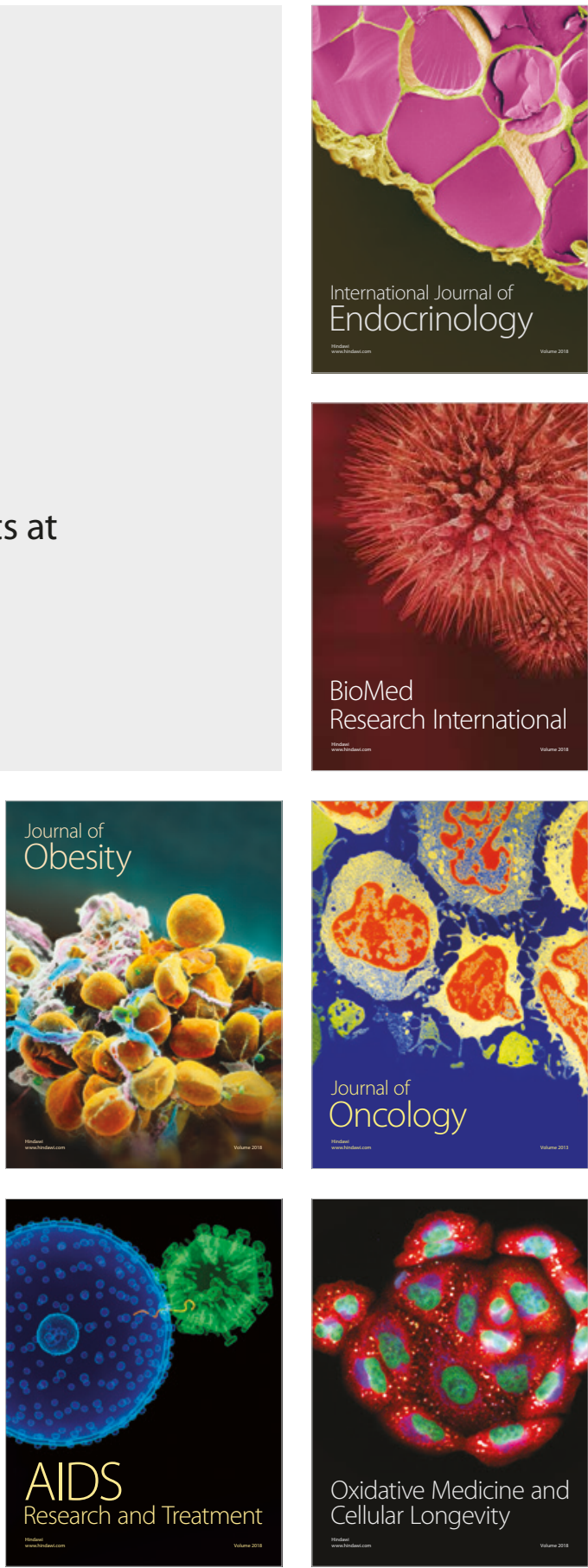